\title{
A STRUCTURAL ANALYSIS OF THE EFQM MODEL: AN ASSESSMENT OF THE MEDIATING ROLE OF PROCESS MANAGEMENT
}

\author{
Eva SUÁREZ1 ${ }^{1}$, José L. ROLDÁN², Arturo CALVO-MORA ${ }^{3}$ \\ ${ }^{1}$ Andalusian Institute of Technology, Research Group on Engineering and \\ Management Knowledge, C/ Leonardo da Vinci, 41092 Seville, Spain \\ ${ }^{2}$ Department of Business Administration and Marketing, \\ University of Seville, Av. Ramón y Cajal, 1, 41018 Seville, Spain \\ ${ }^{3}$ Department of Business Administration and Marketing, \\ University of Seville, Av. Ramón y Cajal, 1, 41018 Seville, Spain \\ E-mails: ${ }^{1}$ esuarez@iat.es; ${ }^{2}$ lroldan@us.es (correspondingauthor); ${ }^{3}$ schmidt@us.es
}

Received 06 June 2012; accepted 12 February 2013

\begin{abstract}
The purpose of this paper is to research how the critical total quality management (TQM) factors present in the European Foundation for Quality Management (EFQM) model make up a management system. This article presents a significant contribution to the current body of TQM by establishing the model's internal working structure as a management system and also by showing how the way in which the organization designs and starts up this system has a bearing on its results. The methodology used is structural equation modeling (Partial Least Squares technique). The sample consisted of 116 firms. Our findings show that: (1) the EFQM model is a reliable and valid framework to measure the results achieved by the firm; (2) The synergies between the critical factors make up a management system, especially, the importance of leadership, strategy and processes for the system's effectiveness and soundness; (3) The obtaining of a measure of the overall results. This allows us to have an overall indicator of the level of excellence attained by the firm; (4) The process management fully mediates the influence of strategy, and alliances and resources management respectively on overall results.
\end{abstract}

Keywords: total quality management, critical factors, overall results, EFQM, excellence, Partial Least Squares (PLS), continuous improvement.

JEL Classification: M10, L25, C31.

\section{Introduction}

A great deal of research has clearly shown how total quality management (TQM) can help organizations to achieve their economic and strategic aims, as well as to obtain excellent results. The indispensable elements for TQM to produce the desired effect are called critical factors. Among those most studied in the literature are: top management leadership and commitment to quality, strategic planning, continuous improvement, 
customer focus, information-based management, human resources management, process control and management and supplier management (Sila, Ebrahimpour 2003).

However, a systematic method or framework is needed to introduce and put into practice the principles, bases and techniques of TQM. For a notable number of researchers (Kim et al. 2010) excellence models or quality awards are suitable frameworks for the TQM implementation.

In Europe, the EFQM model is the most well-known and widespread reference when introducing and improving a TQM system (Kim et al. 2010). The EFQM model is the reference for other models at a national and regional level in Europe.

These models cannot be considered as mere assessment tools (Farris et al. 2011). This is why they have been considered in a wide variety of research carried out on the following topics: the level of integration and satisfaction of people (Tutuncu, Kucukusta 2010), the organizational commitment to quality (Tutuncu, Kucukusta 2007), the analysis of the effectiveness when applying certain management practices concerning teamwork (Castka et al. 2003), technological and management innovations (SantosVijande, Álvarez-González 2008), motivation (Davies 2008), work conditions (Nabitz et al. 2009), the market orientation level and the development of commercial capacities (Santos-Vijande, Álvarez-González 2009), the identification and application of best practices among organizations (Castka et al. 2004) and the degree of commitment to sustainable development values (Olaru et al. 2010).

As far as the methodology is concerned, the most used are case studies and the most analyzed topics refer to the measuring of the organizational performance, the underlying paradigm in the model, and the influence of leadership and human resources management in excellence. However, there is a lack of research that deals with investigating: (a) the role played by factors such as strategy, alliances and resources or process management in excellence management; (b) the relationships that are produced between critical TQM factors and these with the results (Williams et al. 2006; Kim et al. 2010); and (c) the identifying of which specific management practices allow organizations to achieve better results (Yousefie et al. 2011).

In this context, this contribution aims to provide evidence about a question that has not been totally resolved in the quality management literature (Sousa, Voss 2002): how to implement quality management in a real business setting? To do so, we use data from the actual processes of self-assessment and external assessment of firms which have applied the EFQM model and its assessment method - the RADAR approach (Hides et al. 2004). Furthermore, from a practical point of view, the results and the conclusions can orientate managers concerning which mechanisms must be dealt with for a correct implementation and improvement of their management system through the EFQM model. In addition, the literature proposes process management as a key mediating variable in the EFQM model (Calvo-Mora et al. 2005; Heras-Saizarbitoria et al. 2012). However, there is a lack of studies that specifically test this mediating function. Therefore, our contribution seeks also to respond the question: is process management a key mediator of the EFQM model? 
More specifically, the objectives of this work are focused on: (1) analyzing the EFQM model's predictive power, reliability and validity to measure the level of organizational excellence; (2) going deeply into the knowledge of how the agents of the EFQM model are interrelated and how the organization can obtain better results through process management; (3) identifying which factors are the most important or influential when managing for excellence and obtaining better results; and (4) assessing the mediator role of processes in the EFQM model.

To achieve its aims this work begins with a review of the literature on TQM and the EFQM model. It then sets out the research model and the hypotheses. Variance-based structural equation modeling (Partial Least Squares - PLS) is used to test the hypotheses postulated. The sample is made up of 116 Spanish private companies that have submitted themselves to assessment processes supervised by external assessors.

\section{Literature review}

\subsection{Total quality management}

TQM is an integral management philosophy that is characterized by establishing principles or basic concepts and practices that lay the foundation for a continuous management improvement (Eriksson, Garvare 2005).

The critical TQM factors can be classified as social or "soft factors", and technical or "hard factors" (Rahman, Bullock 2005). The social issues are focused on human resources and leadership, teamwork, training and participation and the workers' commitment to quality stand out. The technical aspects reflect an orientation toward the improvement of the production and the processes and methods. These aim to establish a work system based on well-defined, measured and controlled procedures that provide the system with predictability. These technical facets will serve as a basis for a constant improvement of the products and services offered to the customers.

In brief, the application of the key or critical TQM factors cannot be carried out separately. These are related to each other and produce synergies between each other (Yousefie et al. 2011) that reflect the TQM initiatives' global character.

The literature suggests that the optimum management of the key TQM factors will lead to an improvement in the results (Kaynak 2003). To appreciate the effects of TQM on the results, the management system must be mature and consolidated. That is, the effects of TQM on the results will occur and will be perceived in the medium and long term (Lemark et al. 1997).

The basic theoretical foundation of this relationship between critical TQM factors and results is based on the supposition that TQM provides greater value for the internal and external customers via the identifying of their needs and expectations, the response capacity to market changes, as well as through the increasing of process efficiency (Prajogo, Sohal 2006). 


\subsection{The EFQM Excellence Model}

The EFQM model presents a non-prescriptive framework that analyzes the relationships between what an organization does and the results that it is able to attain, assuming that there are different approaches to attaining excellence (Ghobadian, Woo 1996).

The criteria that the model proposes represent the indicative elements of the progression degree that an organization would follow to achieve excellence. These criteria, or dimensions, are specified in five key implementation factors or facilitating agents (what the organization "does and how it does it"). Furthermore, the model offers four dimensions that reflect the results that the organization attains, concerning its customers, employees, society and other key results.

The EFQM model's internal structure reflects the integral character of the TQM's initiatives and considers the interrelationships both in the agent criteria and the criteria results. The correlations that exist between the agent criteria allow a correct design, implementation and development of them that leads to the optimization of the results (Bou-Llusar et al. 2009).

Thus, the key implementation factors cover people, processes, structures, and resources that the organization can use to manage quality (Zairi, Alsughayir 2011). These activities are not independent, that is to say, they must be applied jointly and coordinately with the aim of achieving excellent results (Eskildsen, Dahlgaard 2000).

\section{Research model and hypotheses}

The research model that we propose is based on the management team - via leadership, commitment, and effective involvement with quality and excellence - having to (1) design, formulate, and implement strategy, (2) effectively manage the human resources at its disposal, as well as (3) develop the alliances and provide the system with resources in order to (4) fulfill its aims and obtain the planned results via the process management.

\subsection{Leadership}

In TQM, the senior management's leadership must be personal and visible, permanent, effective and spread to all the management levels (Dean, Bowen 1994). What is more, the senior management must act as a guide and driving force of the TQM implementation. It must create and disseminate the values of this management philosophy, establish coherent goals with these values and design an appropriate management system to achieve them. Leadership is thus considered to be one of the most important factors for the TQM's success (Fotopoulos, Psomas 2010).

Yet to achieve success it is not enough to have the management's commitment. It must also show its involvement via investment in human, material and financial resources that support the achievement of the goals and the improvement of all the processes as well as the development of the strategy (Jabnoum, Sedrani 2005).

From what has been said, we can set out the following hypotheses: 
H1a: Leadership is positively related to people management.

H1b: Leadership is positively related to policy and strategy.

H1c: Leadership is positively related to partnerships and resources.

\subsection{Policy and strategy}

Quality management is a strategic issue for organizations (Prajogo, Sohal 2006), although, as Dean and Bowen (1994) point out, quality affects strategic implementation more than strategic choice. On the other hand, Reed et al. (2000) and Prajogo and Sohal (2004) maintain that TQM can be used in different strategic contexts, both for obtaining a costs advantage and in differentiation. Differentiation is associated with stakeholders' orientation and costs advantage with the process orientation.

The organizational strategy must be based on the current and future needs and expectations of the stakeholders and take into account the particularities of the market the organization is working in. To make strategy a reality, the organization develops and deploys policies, plans, goals and processes based on performance indicators (EFQM 2003).

In this sense, Winn and Cameron (1998) maintain that once it has been designed, the strategy must be put into practice through the deployment of key processes, a right human resources management, and the establishing of alliances and other types of cooperation agreements. Powell (1995) notes how the adopting and communication of the TQM philosophy and principles are upheld in the mission, vision and strategies. It is a question of passing from ideas to facts. This is achieved through the appropriate carrying out of the organization's key processes (Hung 2006).

From the above, we can put forward the following hypotheses:

H2a: Policy and strategy is positively related to people management.

H2b: Policy and strategy is positively related to process management.

H2c: Policy and strategy is positively related to partnerships and resources.

\subsection{People}

Human resources management is one of the factors around which revolves an important part of the TQM's success (Ahmad, Schroeder 2002). This is because the process of quality improvement is an organizational learning process in which the human factor is a critical resource. This leads to people being less substitutable and more interchangeable within the organization.

Claver et al. (2003) highlight as critical TQM practices concerning the people management the following: training, teamwork and learning. In this vein, training and learning must be developed at all the organizational levels (Anderson et al. 1994).

In addition, other essential activities are a right selection, reward and development of the workers (Flynn et al. 1994), the establishing of career development plans (Soltani et al. 2004), and the participation in the goals setting and reviewing in their responsibility areas (Fotopoulos, Psomas 2010). Also, the organization must aim to achieve 
the commitment and involvement of all the personnel (Tutuncu, Kucukusta 2007). In exchange, their participation in decision making (empowerment) and improvement activities must be facilitated. To conclude, an appropriate management of people must influence the correct carrying out and improvement of the organization's processes. These will lead to obtaining better results.

From the aforementioned, we set out the following hypothesis:

H3: People management is positively related to process management.

\subsection{Partnerships and resources}

According to the EFQM model (2003), alliances and other forms of the organizational cooperation must be managed, as well as the economic-financial resources, the infrastructures and other intangible resources such as technology, information and knowledge.

Cooperation with suppliers is imperative for all management systems that aim to attain success, as it is a key link in the value chain of all organizations (Wrong 2002). Firms must make an effort in order to commit suppliers in specific operations and internal processes, and work closely with them. This is because these activities contribute to fostering excellence from the first phases of product manufacturing and to generating value for the end customers (Criado, Calvo-Mora 2009). On the other hand, counting on the appropriate infrastructures and efficiently managing the economic resources facilitates the carrying out of the firm's processes (Yousefie et al. 2011). It is also indispensable to have access to information concerning quality, the achievements that are being attained in the organizational performance indicators, the customers' satisfaction levels and the evolution of the customer needs. This is a basis for undertaking improvements and a way of adapting to the changes that are taking place in the organization's environment (Ahire et al. 1996). In this sense, the organization must use knowledge about the market, stakeholders or competitors and incorporate them into the key processes in order to achieve the planned results (Bou-Llusar et al. 2009).

In accordance with our presentation so far, we therefore propose the following hypothesis:

H4: Partnerships and resources are positively related to process management.

\subsection{Processes}

The management and improvement of processes is, along with leadership, the key factor for effective quality implementation that has the greatest consensus in the TQM literature (Curkovic et al. 2000).

The EFQM model establishes process management as being the nexus of union between the remaining key implementation factors and the measures of the results. In this sense, Claver et al. (2003) point out that organizations act more effectively in achieving their aims and in obtaining better results when all their activities are systematically developed, managed and improved through processes. 
In the industrial area, process management implies the development of activities such as the management, control and improvement of all the phases of design and manufacturing, the preventative maintenance of teams, the statistical control of processes, and the reduction of inspections or process variability (Fotopoulos, Psomas 2010). These aspects are positively related to productivity or economic efficiency (Curkovic et al. 2000). To compete in the markets, firms must back the prevention of errors and a key process management that leads them to fulfill customers' requirements and specifications and the achievement of excellent results.

In the services area, process management is associated with service provision (Prajogo 2005). This is the determining factor of how clients perceive its quality and, therefore, their satisfaction level. Perception is assessed via tangible elements, reliability, security, empathy, and responsiveness (Parasuraman et al. 1994).

From the aforementioned, we can put forward the following hypothesis:

H5: Process management is positively related to overall results.

\subsection{Overall results}

Much literature on the effects of the TQM in firms reaches the conclusion that this leads to an improvement in performance and results. The measures used to analyze the results are very varied. Amongst them, internal objective measures have been found, such as costs reduction, productivity gains (Jabnoun, Sedrani 2005), innovation performance, and the improvement of processes (Sila, Ebrahimpour 2005). Subjective measures, such as internal and external customer satisfaction, and the organization's image and reputation tend to be used (Jabnoun, Sedrani 2005) and, above all, financial measures such as sales, profitability, benefits or the stock market price (Hendricks, Singhal 2001). The EFQM model grouped the previous measures into four categories of results: Customers, People, Society and Key results of the business. In line with their strategic goals, these are the results that organizations achieve. Furthermore, measures and indicators - both subjective and objective - are considered in the results, as well as tendencies or the carrying out of benchmark-based comparisons.

\section{Methodology}

\subsection{Sample}

The sample is made up of 116 Spanish private firms which have been candidates for regional excellence awards and which use the EFQM model as a framework (Table 1). There are both small and medium-sized firms (SMEs) and large firms. For this purpose, and according to the European Commission's definition, an SME is considered to be one that employs less than 250 people and whose annual turnover does not exceed 50 million euros or whose annual balance sheet is not over 43 million euros ${ }^{1}$.

\footnotetext{
${ }^{1}$ The potential influence of the sample heterogeneity, according to the firm size, has been tested. In this vein, we have applied a multigroup analysis comparing SMEs and large firms subsamples. The results practically show no significant differences both in the measurement model and the structural model.
} 
Table 1. Sample characteristics

\begin{tabular}{lcc}
\hline & Frequency & Percentage \\
\hline Company size & & \\
\hline Small and medium & 56 & 48.3 \\
\hline Large & 60 & 51.7 \\
\hline Total & 116 & 100 \\
\hline Type of business & & \\
\hline Services & 55 & 47.41 \\
\hline $\begin{array}{l}\text { Manufacturing and } \\
\text { construction }\end{array}$ & 51 & 43.97 \\
\hline Agriculture and mining & 10 & 8.62 \\
\hline Total & 116 & 100 \\
\hline
\end{tabular}

\subsection{Measures and data}

The data have been obtained from the results of the assessment process of firms from the year 2003 to 2009. This assessment was carried out through the 2003 EFQM model and the RADAR logic (i.e., Results, Approach, Deployment, Assessment and Review). The RADAR logic is a dynamic assessment framework and a powerful management tool that provides a structured approach to questioning the performance of an organization (Williams et al. 2006). Specifically the approach, deployment, assessment and review elements are applied for the model's facilitating agents and the evidence of how the management is being developed must be analyzed. The results element is used to assess what the organization is achieving as a consequence of its management, and evidence and specific measures of the results achieved must be provided (Hides et al. 2004).

Most studies that analyze the internal structure of the EFQM model's relationships do not use the original measurement scales or the scores obtained through the RADAR matrixes. On the contrary, these studies have developed perceptual scales adapted from the EFQM model structure. This is the case of the contributions of Calvo-Mora et al. (2005) and Bou-Llusart et al. (2009).

The literature confirms the theoretical reliability of the data obtained through the validation carried out by independent external experts (Pannirselvam, Ferguson 2001). Furthermore, as Kim et al. (2010) point out, excellence models offer the suitable theoretical framework for TQM implementations in organizations. In this sense, the criteria and subcriteria used by excellence models to measure the TQM correspond to the constructs and measures validated by other TQM studies (c.f., Anderson et al. 1994; Powell 1995; Sila, Ebrahimpour 2003). The reliability and validity of the original measures of the EFQM model have been also confirmed by Heras-Saizarbitoria et al. (2012).

This study uses six variables, five of them modeled as first-order constructs. That is, we considered that these theoretical concepts are inferred from manifest variables or indicators. 
We refer to the leadership, policy and strategy, people, partnerships and resources, and processes variables. On the other hand, the results variable has been designed as a multidimensional construct. This means that the results variable consists of a number of dimensions and it is measured by such first-order factors, that is to say, key, people, customer, and society results dimensions (Polites et al. 2012).

\subsection{Assessment of epistemic relationships}

An epistemic relationship or measurement model describes the link between theory (constructs) and data (indicators). This is also applicable to the bonds between a multidimensional construct and its dimensions. According to Roberts and Thatcher (2009), both the five first-order constructs (leadership, policy and strategy, people, partnerships and resources, and processes variables) and the four dimensions (key, people, customer, and society results) have been considered as reflective constructs. The results variable, in turn, has been modeled as an aggregate construct (Polites et al. 2012). That is, it is a composite of its four dimensions.

\section{Data analysis and results}

\subsection{Partial Least Squares}

The research model proposed in Figure 1 has been tested using a variance-based structural equation modeling (i.e., Partial Least Squares - PLS) (Reinartz et al. 2009). The use of PLS is justified by the following reasons (Roldán, Sánchez-Franco 2012): (1) this study is oriented toward the prediction of the dependent variables; (2) the research model is complex, both in the number of variables (manifest and latent) and in the hypothesized relationships; (3) the sample ( $\mathrm{n}=116)$ is small and, according to Reinartz et al. (2009), PLS should be applied when the number of observations is lower than 250; (4) the research model includes

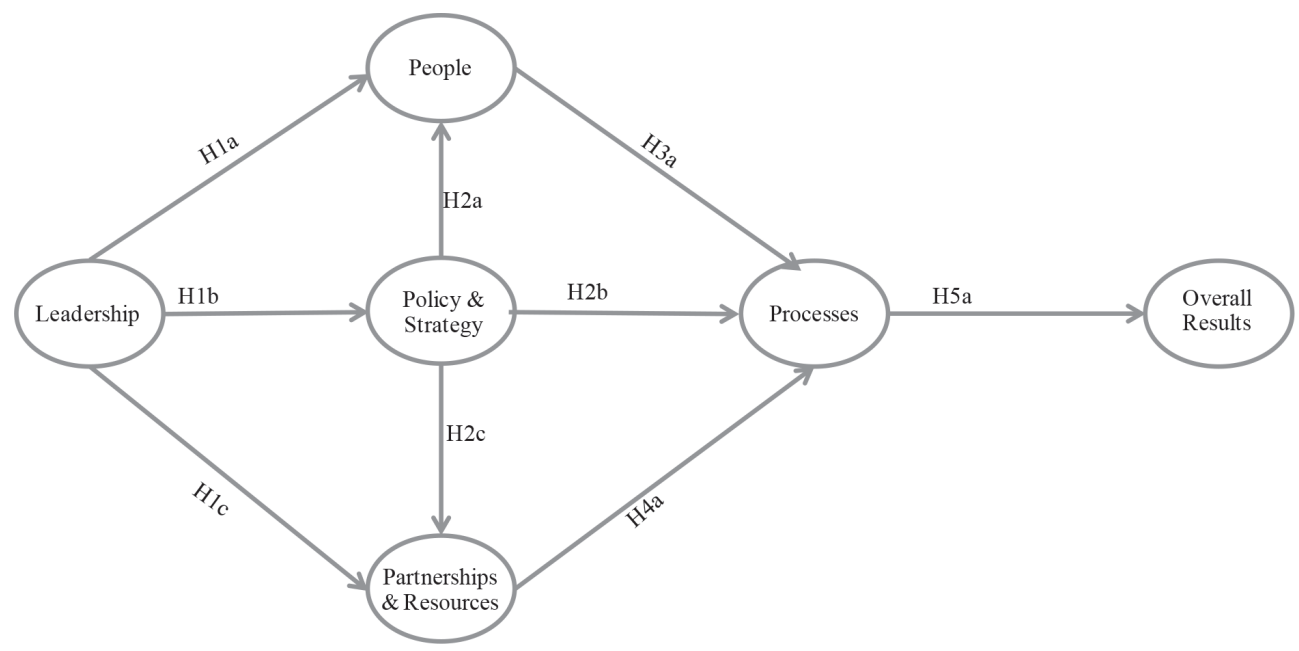

Fig. 1. Research model and hypotheses 
a final variable with formative relationships (overall results), which impedes the use of a covariance-based structural equation model due to an irresolvable problem of indeterminacy (see MacCallum, Browne 1993); (5) this study uses latent variables scores in the subsequent analysis for a predictive relevance; (6) finally, the use of secondary data in this study makes the utilizing of PLS advisable. This study uses PLS-Graph software (Chin 2003).

Concerning the multidimensional aggregate construct, the results variable, we followed a two-step approach. Thus, items for each dimension were optimally weighted and combined using the PLS algorithm in order to create a latent variable score.

\subsection{Measurement model assessment}

\section{Evaluation of reflective measurement models}

Individual item reliability is assessed by analyzing the standardized loadings $(\boldsymbol{\lambda})$. In our study, all indicators surpass the minimum level of 0.707 (Table 2). Construct reliability is appraised using the composite reliability $\left(\rho_{c}\right)$ as a measure of internal consistency. In our research, all constructs are reliable (Table 2) since they have internal consistency measures that exceed $0.8860\left(\rho_{c}\right)$. Convergent validity is assessed via the average variance extracted (AVE). AVE values should be greater than 0.50 (Roldán, SánchezFranco 2012). Consistent with this suggestion, AVE measures for all variables exceed 0.666 (Table 2). For an adequate discriminant validity, the square root of the AVE of each construct should be greater than its correlations with any other latent variable. All constructs satisfy this condition (Table 3 ).

\section{Evaluation of the formative measurement model}

The formative measurement model, at the dimension level, is examined by assessing the potential multicollinearity and the magnitude of the weights.

Using the SPSS program, we test the variance inflation factor (VIF) of each dimension. Our data are far below the common cut-off threshold of 3.3 (Roberts, Thatcher 2009). Thus, multicollinearity does not pose a threat to the validity of our aggregate multidimensional construct (Table 2).

The interpretation of constructs with formative dimensions should be based on the weights (Roldán, Sánchez-Franco 2012). These provide information about how each formative dimension contributes to the respective aggregate multidimensional construct. Three dimensions present significant weights in the results variable (customer, people and key results), which means that such first-order factors explain a significant portion of the variance in the multidimensional construct (Table 2). In addition, taking into account the magnitude of the weights shown by the four dimensions, it could be observed that the customer (0.3643) and people (0.3417) first-order factors represent the most important dimensions in the make-up of the results variable.

\subsection{Structural model assessment}

The structural model is assessed analyzing the coefficient of determination $\left(R^{2}\right)$ of the endogenous constructs, the algebraic sign, magnitude and significance of the path 

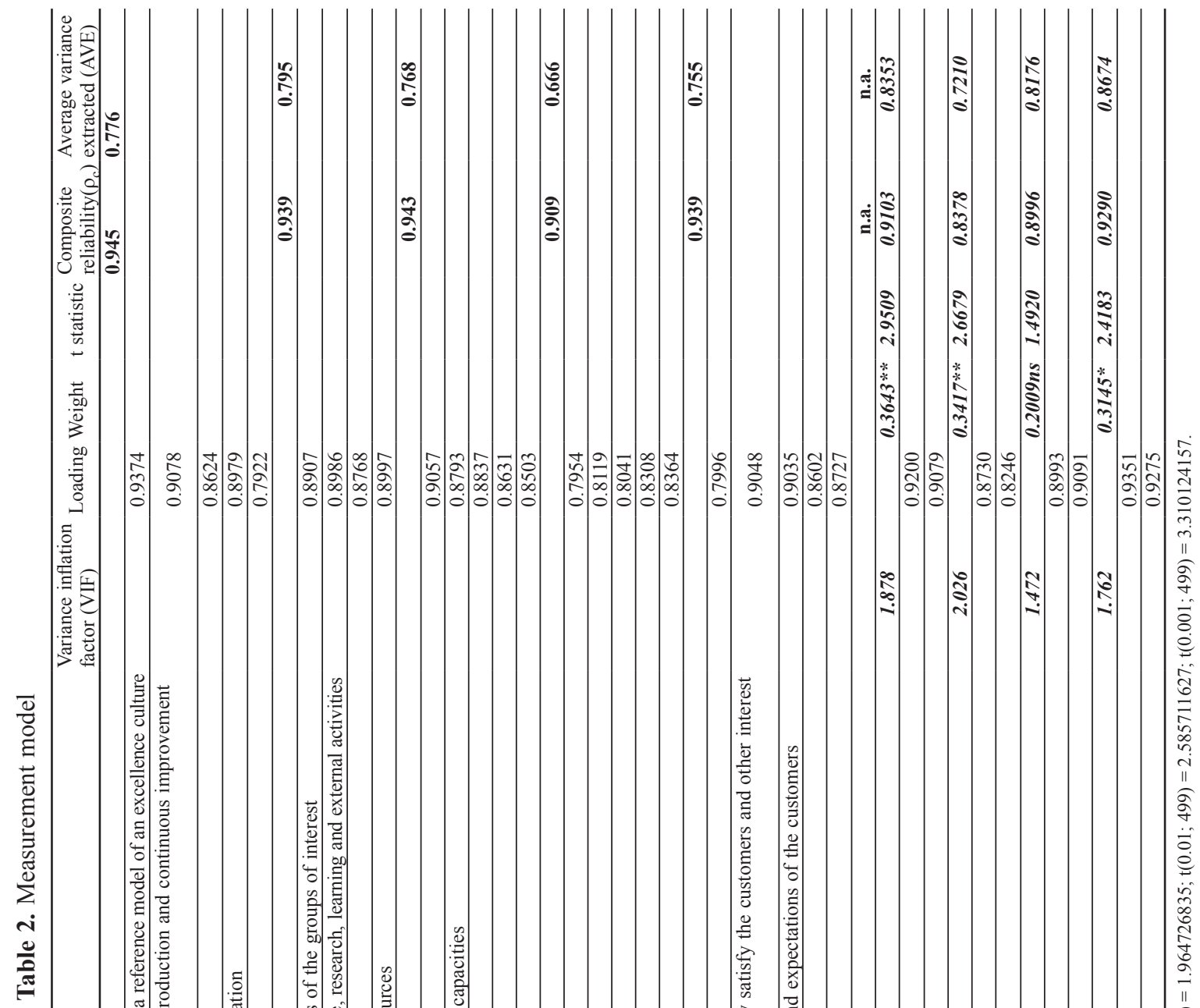

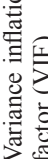

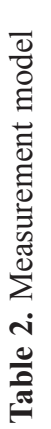

을

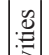

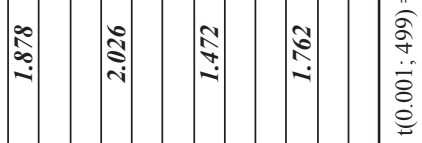

흘

흏

気

氶

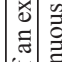

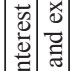

岁言

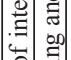

:

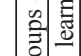

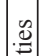

竞:

焉

学.

:

莺言

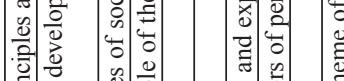

들

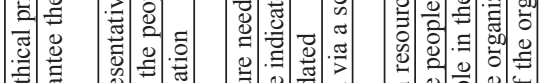

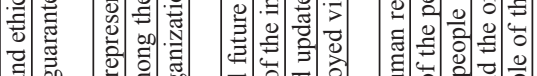

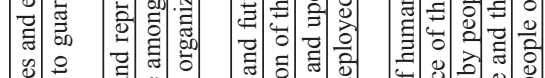

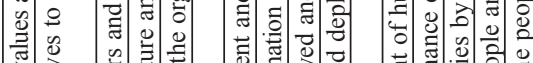

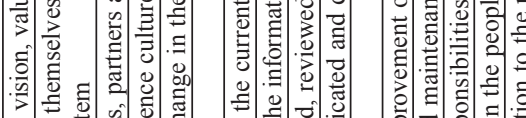

:

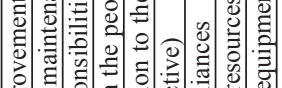

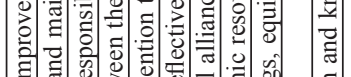

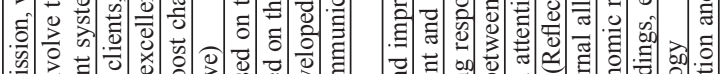

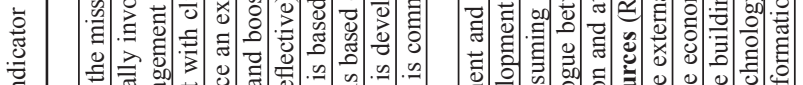

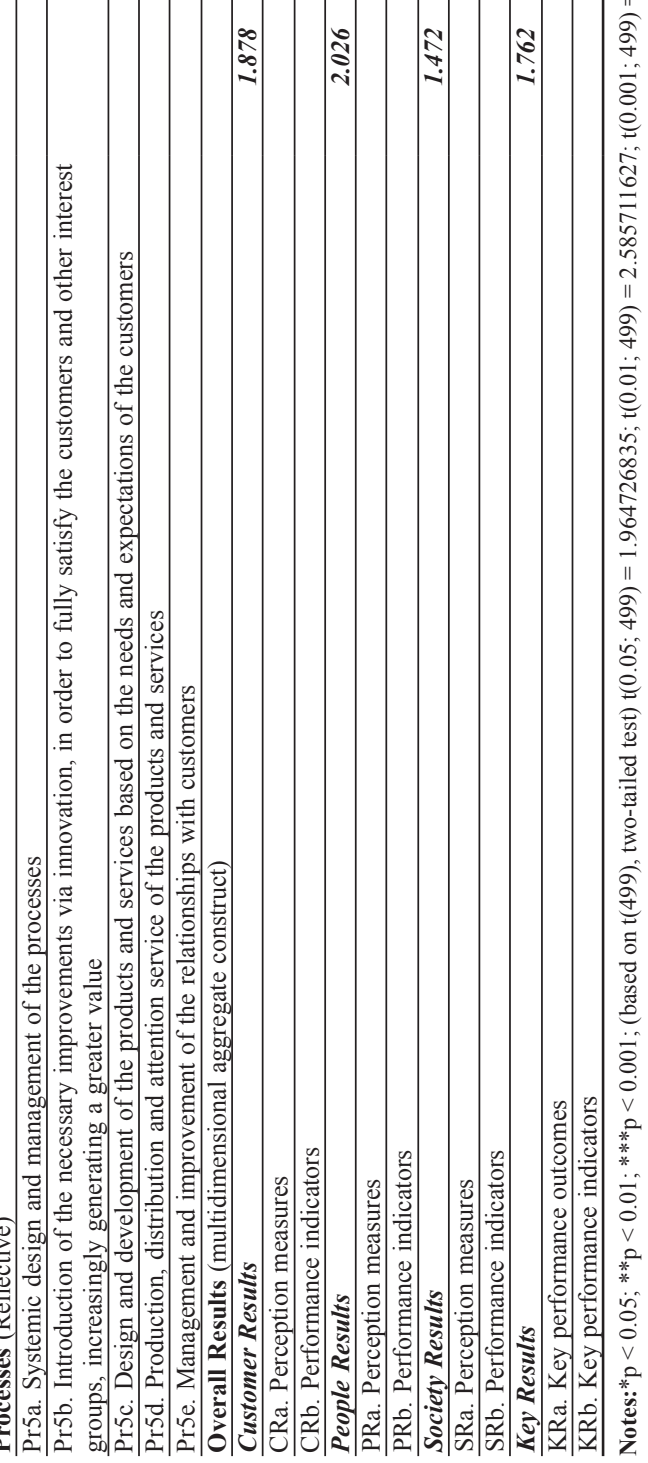


Table 3. Discriminant validity

\begin{tabular}{lcccccc}
\hline & Leadership & People & $\begin{array}{c}\text { Policy \& } \\
\text { Strategy }\end{array}$ & $\begin{array}{c}\text { Partnerships \& } \\
\text { Resources }\end{array}$ & Processes & $\begin{array}{c}\text { Overall } \\
\text { Results }\end{array}$ \\
\hline Leadership & 0.881 & & & & & \\
\hline People & 0.842 & 0.876 & & & & \\
\hline Policy \& Strategy & 0.830 & 0.780 & 0.892 & & & \\
\hline $\begin{array}{l}\text { Partnerships \& } \\
\text { Resources }\end{array}$ & 0.762 & 0.725 & 0.846 & 0.816 & & \\
\hline Processes & 0.719 & 0.655 & 0.792 & 0.759 & 0.869 & \\
\hline Overall Results & 0.640 & 0.602 & 0.652 & 0.645 & 0.689 & n.a. \\
\hline
\end{tabular}

Notes: Diagonal elements (italics) are the square root of variance shared between the constructs and their mea- sures (AVE). Off-diagonal elements are the correlations among constructs. For discriminant validity, the diagonal elements should be larger than the off-diagonal elements. n.a.: not applicable.

coefficients, and the predictive relevance of the endogenous reflective variables $\left(Q^{2}\right)$ (Roldán, Sánchez-Franco 2012).

Table 5 shows the $R^{2}$ values of the model's endogenous variables. In this vein, the model has an appropriate predictive power because all dependent constructs have coefficients of determination that exceed 0.47 , having an average explained variance of $65.5 \%$. This average value practically represents a substantial level of explanatory power for the entire model.

Bootstrapping (500 resamples) was used to generate standard errors and t-statistics. This allows us to assess the statistical significance of the path coefficients. The results for tvalues allow us to observe that eight path coefficients are significant. In addition, the results for the algebraic signs are all positive. Accordingly, we have found support for eight of the nine hypotheses proposed (Table 4). Table 5 shows the disaggregated explained variance of the endogenous constructs according to the effect of each antecedent variable. The predictive relevance of the structural model has been tested following the StoneGeisser $Q^{2}$. A $Q^{2}$ greater than 0 implies that the model has predictive relevance. Our structural model satisfies this condition because all $Q^{2}$ values presented in Table 5 are positive (Roldán, Sanchez-Franco 2012).

\subsection{An assessment of the mediator role of process management}

Our research model contains many potential indirect effects. The analysis of such a large set of mediated relationships exceeds the aim of our current contribution. Nevertheless, the literature points out the key mediator role that process management may play in the EFQM model (Calvo-Mora et al. 2005; Heras-Saizarbitoria et al. 2012). In addition, we observe a lack of studies that specifically test the mediating function of the processes construct. Therefore, we aim to analyze in this section the mediator role of the processes in the EFQM model. To this end, we examine how three variables (people, policy \& 
Table 4. Structural model results

\begin{tabular}{lccc}
\hline Hypotheses & Path coefficients & $\begin{array}{c}t \text {-value } \\
\text { (bootstrap) }\end{array}$ & Support \\
\hline H1a: Leadership $\rightarrow$ People & $0.626^{* * *}$ & 5.5450 & Yes \\
\hline H1b: Leadership $\rightarrow$ Policy \& Strategy & $0.830^{* * *}$ & 25.2079 & Yes \\
\hline H1c: Leadership $\rightarrow$ Partnerships \& Resources & $0.192^{*}$ & 2.1864 & Yes \\
\hline H2a: Policy \& Strategy $\rightarrow$ People & $0.260^{*}$ & 2.1053 & Yes \\
\hline H2b: Policy \& Strategy $\rightarrow$ Processes & $0.501^{* * *}$ & 4.7911 & Yes \\
\hline H2c: Policy \& Strategy $\rightarrow$ Partnerships \& & $0.687^{* * *}$ & 8.4474 & Yes \\
Resources & $0.046^{\mathrm{ns}}$ & 0.4508 & No \\
\hline H3: People $\rightarrow$ Processes & $0.302^{* *}$ & 3.0148 & Yes \\
\hline H4: Partnerships \& Resources $\rightarrow$ Processes & $0.689^{* * *}$ & 14.7815 & Yes \\
\hline H5: Processes $\rightarrow$ Overall Results & & &
\end{tabular}

Notes: ${ }^{*} \mathrm{p}<0.05 ; * * \mathrm{p}<0.01 ; * * \mathrm{p}<0.001 ;{ }^{\mathrm{ns}}$ : not significant (based on $\mathrm{t}(499)$, one-tailed test) $\mathrm{t}(0.05 ; 499)=1.64791345 ; \mathrm{t}(0.01 ; 499)=2.333843952 ; \mathrm{t}(0.001 ; 499)=3.106644601$.

Table 5. Effects on endogenous variables

\begin{tabular}{|c|c|c|c|c|c|}
\hline Endogenous variables & $R^{2}$ & $Q^{2}$ & Exogenous variables & $\begin{array}{l}\text { Direct } \\
\text { effect }\end{array}$ & $\begin{array}{l}\text { Variance } \\
\text { explained }\end{array}$ \\
\hline Policy \& Strategy & 0.688 & 0.5221 & Leadership & 0.830 & $68.89 \%$ \\
\hline People & 0.729 & 0.5410 & $\begin{array}{l}\text { Leadership } \\
\text { Policy \& Strategy }\end{array}$ & $\begin{array}{l}0.626 \\
0.260\end{array}$ & $\begin{array}{l}52.71 \% \\
20.28 \%\end{array}$ \\
\hline $\begin{array}{l}\text { Partnerships \& } \\
\text { Resources }\end{array}$ & 0.727 & 0.4613 & $\begin{array}{l}\text { Leadership } \\
\text { Policy \& Strategy }\end{array}$ & $\begin{array}{l}0.192 \\
0.687\end{array}$ & $\begin{array}{l}14.63 \% \\
58.12 \%\end{array}$ \\
\hline Processes & 0.656 & 0.4627 & $\begin{array}{l}\text { Policy \& Strategy } \\
\text { People } \\
\text { Partnerships \& Resources }\end{array}$ & $\begin{array}{l}0.501 \\
0.046 \\
0.302\end{array}$ & $\begin{array}{c}39.68 \% \\
3.00 \% \\
22.92 \%\end{array}$ \\
\hline Overall Results & 0.475 & n.a & Processes & 0.689 & $47.50 \%$ \\
\hline
\end{tabular}

Note: n.a.: not applicable.

strategy, and partnerships \& resources) impact an endogenous variable (overall results) through a mediating variable (processes). Consequently, we assess the total and direct effects of people, policy \& strategy, and partnerships \& resources constructs on the dependent variable (overall results), and the indirect effects via the mediator (processes).

A recommended approach for testing mediating effects is bootstrapping (Preacher, Hayes 2008). Using latent variables scores obtained from the PLS analysis, we have applied the SPSS routine developed by Preacher and Hayes (2008) to calculate 95 percent percentile confidence intervals (CI) for the mediator variable. When an interval for a mediating effect does not contain zero, it means that the indirect effect is significantly different from zero with a $95 \%$ confidence level. 
Figure 2A describes the total effects of people $(e)$, policy \& strategy $(f)$, and partnerships $\&$ resources $(g)$ on overall results. These total effects may be arrived at via a variety of direct and indirect forces. For instance, Figure 2B graphically describes how the total effect of partnerships \& resources $(g)$ on overall results can be expressed as the sum of the direct $\left(g^{\prime}\right)$ and indirect effect $\left(c^{*} d\right)$. Accordingly, $g=g^{\prime}+c^{*} d$. Thus, this approach allows to isolate the indirect effect $\left(c^{*} d\right)$. The relationships $g$ and $g^{\prime}$, although nonhypothesized, are included in our analysis in order to test the presence of either full or partial mediation. The same procedure is applicable to the total effect of people, and policy \& strategy on overall results respectively.

Table 6 shows the results of the mediating effect test. The people variable has a significant total effect on overall results $(e=.2132$, t-value $=1.6509)$ (Fig. 2A). When the processes variable is introduced as a mediator, the people construct slightly reduces

\section{A. Model with total effects}

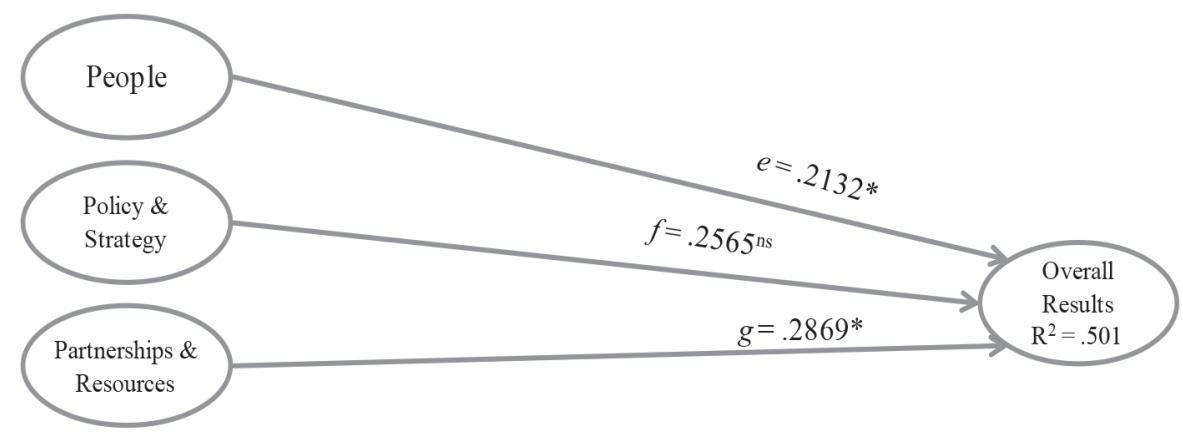

B. Model with mediated effects

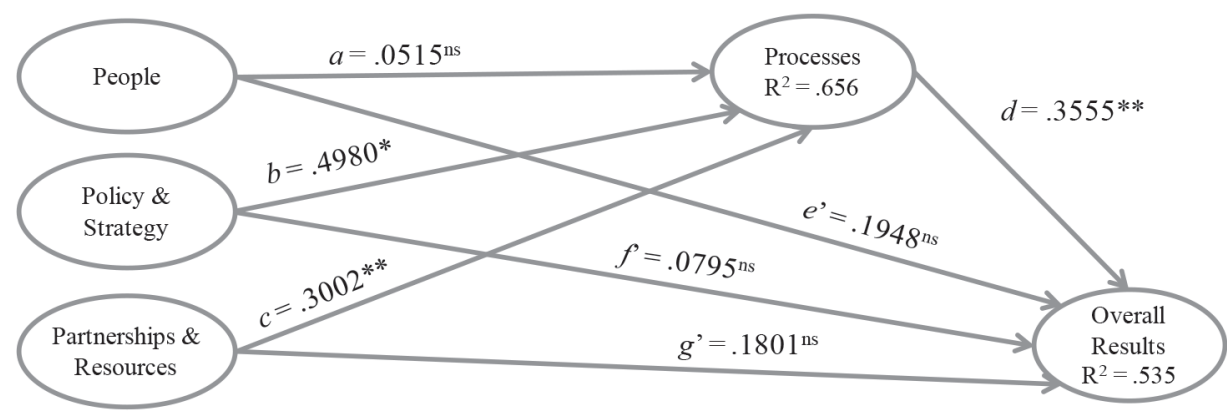

$$
\text { People } \rightarrow \text { Processes } \rightarrow \text { Overall Results }=\mathrm{a}^{*} \mathrm{~d}
$$

Policy \& Strategy $\rightarrow$ Processes $\rightarrow$ Overall Results $=b^{*} \mathrm{~d}$

Partnerships \& Resources $\rightarrow$ Processes $\rightarrow$ Overall Results $=\mathrm{c}^{*} \mathrm{~d}$

Fig. 2. The mediator role of process management

Notes: ${ }^{* * *} \mathrm{p}<0.001,{ }^{* *} \mathrm{p}<0.01,{ }^{*} \mathrm{p}<0.05,{ }^{\text {ns }}=$ not significant (based on $\mathrm{t}(4999)$ ), one-tailed test). 
Table 6. Summary of mediating effect test

\begin{tabular}{|c|c|c|c|c|c|c|}
\hline & \multirow[t]{3}{*}{ Total effect } & \multicolumn{2}{|c|}{ Direct effect to } & \multicolumn{3}{|c|}{ Indirect effects } \\
\hline & & \multirow[b]{2}{*}{ Proc } & \multirow[b]{2}{*}{ OR } & \multirow{2}{*}{ Estimate } & \multicolumn{2}{|c|}{$\begin{array}{c}\text { Percentile } \\
\text { bootstrap } 95 \% \\
\text { confidence interval }\end{array}$} \\
\hline & & & & & Lower & Upper \\
\hline $\mathrm{P} \rightarrow \mathrm{OR}$ & $.2132 *(1.65)$ & & & & & \\
\hline $\mathrm{S} \rightarrow \mathrm{OR}$ & $.2565^{\mathrm{ns}}(1.38)$ & & & & & \\
\hline $\mathrm{P} \& \mathrm{R} \rightarrow \mathrm{OR}$ & $.2869 *(1.82)$ & & & & & \\
\hline $\mathrm{P}$ & & $.0515^{\mathrm{ns}}(.50)$ & $.1948^{\mathrm{ns}}(1.56)$ & & & \\
\hline$S$ & & $.4980 * * *(4.53)$ & $.0795^{\mathrm{ns}}(.36)$ & & & \\
\hline$P \& R$ & & $.3002 * *(2.99)$ & $.1801^{\mathrm{ns}}(1.09)$ & & & \\
\hline Proc & & & $.3555^{* *}(2.52)$ & & & \\
\hline $\begin{array}{l}\mathrm{P} \rightarrow \text { Proc } \rightarrow \\
\mathrm{OR}=a^{*} d\end{array}$ & & & & .0183 & -.0554 & .0949 \\
\hline $\begin{array}{l}\mathrm{S} \rightarrow \text { Proc } \rightarrow \\
\mathrm{OR}=b^{*} d\end{array}$ & & & & .1770 & .0654 & .3190 \\
\hline $\begin{array}{l}\mathrm{P} \& \mathrm{R} \rightarrow \text { Proc } \\
\rightarrow \mathrm{OR}=c^{*} d\end{array}$ & & & & .1067 & .0230 & .2342 \\
\hline
\end{tabular}

Notes: P: People; S: Policy \& Strategy; P\&R: Partnership \& Resources; Proc: Processes; OR: Overall Results.

$* \mathrm{p}<.05, * * \mathrm{p}<.01, * * * \mathrm{p}<.001,{ }^{\mathrm{n} s}=$ not significant, based on $t(4999)$, one-tailed test: $t(0.05$, $4999)=1.645158499, t(0.01 .4999)=2.327094067, t(0.001,4999)=3,091863446 / t$-values in parentheses. Bootstrapping $95 \%$ confidence interval based on 5,000 bootstrap samples.

its direct effect on overall results and becomes non-significant $\left(e e^{\prime}=.1948\right.$, t-value $=$ 1.5621) (Fig. 2B), while its indirect effect via the processes variable achieves a point estimate of $.0183\left(a^{*} d\right)$ (Table 6). Since its CI contains zero, the indirect effect is also non-significant. This means that the processes construct does not mediate the influence of the people variable on overall results. On the other hand, the policy \& strategy variable has a non-significant total effect on overall results $(f=.2565$, t-value $=1.3844)$ (Fig. 2A). When the processes variable is included in the model, policy \& strategy maintains a non-significant direct effect on overall results $\left(f^{\prime}=.0795\right.$, t-value $\left.=.3607\right)$ (Table 6, Fig. 2B). However, the indirect effect mediated through processes has a significant point effect of $.177\left(b^{*} d\right)$ while its CI does not present any sign change (Table 6). Therefore, the processes variable mediates the influence of policy \& strategy on overall results. Finally, our analysis reveals a full mediation of the processes construct in the relationship between partnerships \& resources and overall results. Initially, the total effect of partnerships \& resources on overall results is significant $(g=.2869, \mathrm{t}=1.824)$ (Table 6, Fig. 2A). Nevertheless, the model with mediated effects (Fig. 2B) unveils how the direct effect decreases and becomes non-significant $\left(g^{\prime}=.1801\right.$, t-value $\left.=1.0929\right)$ 
whereas the indirect effect via the processes variable $\left(c^{*} d\right)$ achieves a significant point estimate of 0.1067 .

\section{Discussions}

The high predictive power stands out in the research model as it presents explained variance $\left(R^{2}\right)$ values over 0.47 , and a high predictive validity by having dependent reflective variables of the $Q^{2}$ coefficient values over 0 .

On the other hand, leadership is a key element for the success of the TQM initiatives and its commitment and involvement must be expressed in the formulating and effective implementation of a set of strategies, policies and actions related to human resources, processes, alliances and resources. This aspect is corroborated in this study by all the hypotheses being supported (Table 4) that represent leadership as a guide and driving force of excellence. This is done through the establishing of policies and strategies (H1b), of the management of people (H1a) and of external alliances and internal resources (H1c). These relationships have also been confirmed by other empirical studies such as those of Calvo-Mora et al. (2005), Flynn and Saladin (2001), Prajogo (2005), Fotopoulos and Psomas (2010) or Eskildsen and Dahlgaard (2000). Furthermore, in Table 5 the notable percentage of explained variance in the dependent variables policy \& strategy (68.89\%), people (52.71\%) and partnerships \& resources $(14.63 \%)$ due to the leadership variable is noted. This is done without considering the indirect effects that this variable has on people and partnerships \& resources through policy \& strategy and on processes through people, partnerships \& resources, and policy \& strategy.

Secondly, the positive relationships between policy \& strategy and people (H2a), processes (H2b) and partnerships \& resources $(\mathrm{H} 2 \mathrm{c})$ are also supported. That is to say, strategy must serve as a reference for the establishing of personal policies, alliances, resources management and processes. The importance for TQM of a well-defined strategy that is implemented and communicated at all the organization's levels is clearly shown (Prajogo 2005; Fotopoulos, Psomas 2010). This relevant role is also seen through the percentage of explained variance that the people $(20.28 \%)$, partnerships \& resources (58.12\%) and processes (39.68\%) variables help to understand.

Thirdly, people do not have a significant effect on processes (H3) and only contribute to $3 \%$ of its explained variance. In this respect, the research does not coincide when verifying this relationship. Flynn and Saladin (2001) find the relationship to be positive and significant, while Fotopoulos and Psomas (2010) and Heras-Saizarbitoria et al. (2012) do not find it to be significant. According to Dahlgaard-Park (2008) some relationships in the EFQM model between enablers and results criteria may be questioned. It is necessary to research the robustness and significance of such relationships from a statistical point of view and, consequently, shed some light on the underlying theory.

Regarding this, we could note as work hypotheses for future research the possibility that organizations have perhaps forgotten to apply one of the basic principles of excellent management when carrying out process management: the participation of people in the 
identifying, systemization and improvement of this system. We set out this possible explanation in the face of verified evidence that people's participation is what generates organizational commitment (Tutuncu, Kucukusta 2007) and that this in turn can bring about a feeling of ownership in the process management that would make the relationship between the people and process management significant. Moreover, if the EFQM model's subcriteria are analyzed in detail with respect to the management of people, a greater dedication to the analysis of to what extent this fosters participation in the continuous improvement processes is missing.

The non-significant link from people management to processes could be explained by some differences between public agencies and private firms (Eskildsen et al. 2004). In this sense, public organizations would put much more emphasis on the people dimension in contrast to private organizations that emphasized the systems dimension (strategy, process, alliances and resources).

Fourthly, results show that the management of alliances and resources has a positive and significant bearing on processes (H4). In this way, the greater the endowment of resources and the better these and alliances are managed, the more effectively the processes will be developed (Eskildsen, Dahlgaard 2000; Calvo-Mora et al. 2005).

With respect to processes, the hypothesis is supported that relates them to results (H5) and the importance of processes when predicting results, explaining $47.5 \%$ of the explained variance of the overall results variable. For Anderson et al. (1995), the way in which the organization develops and improves its key activities is the main decisive factor of the people and customer satisfaction results.

Excellent organizations must design, manage and improve their key processes to satisfy and generate increasingly more value for their stakeholders (Prajogo 2005). The outcomes of these actions and the orientation of the processes to the stakeholders is that the organization improves its results in people, customers, owners or society in general (Fotopoulos, Psomas 2010).

Moreover, the processes play a key mediating role in the relationships of the variables policy \& strategy, and partnerships \& resources with overall results. The influence of these variables on the results is channeled through the process management, which organizations carry out to fulfill the stakeholders' expectations and to achieve a high organizational performance.

Hence, it is confirmed that the processes are the nexus of union between the critical factors of quality implementation and the results (EFQM 2003). Thus, organizations should pay special attention to the identifying, managing and improving of their critical processes as they are a key piece for the quality management system to produce the desired effects on the business' main results. On the other hand, process management does not play a mediating role between the people management and the results. Indeed, it is interesting to note that the direct relationship between the people management and the overall results (Table 6, Fig. 2B) almost becomes significant. This result is found to be close to that of the study of Nair (2006), which identifies direct relationships between the people management and financial and operational performance. That is why 
we think that the influence of the people management on results could become more direct than indirect through the processes.

Regarding the overall results, the customer dimension achieves the most important weight $(0.364)$, followed very closely by the results in people $(0.347)$ and the key business results with 0.315 . Finally, the lowest contribution of the results is that of the firm's social impact (0.201). Furthermore, this latter value is not significant (see Table 2). These results coincide with those obtained in other, similar research, such as that of Eskildsen et al. (2001).

\section{Conclusions}

From a theoretical point of view, the work goes more deeply into a question that has not been totally resolved in the quality management field (Sousa, Voss 2002): How to implement quality management in a real business setting? Thus, from the results obtained, we can conclude that in order to achieve excellent results it is indispensable to manage all the facilitating agents included in the EFQM model. Furthermore, these agents do not perform effectively if they are implemented in an isolated manner. On the contrary, there are important relationships and synergies between them, which make up a management system. This system must have three related groups of factors: (1) the so-called soft factors, associated with people and their behaviors and attitudes; (2) the hard factors, that is, the technical component of the quality system, and (3) a policy and strategy which establishes the goals and orientates and coordinates the actions which are developed within the quality system.

These aims could not be achieved without the drive and the leadership of the management and the human resources as a main asset of the organization. Yet the soft or social factors are not enough to attain the planned aims and results. It is indispensable to count on a technical structure which allows people's efforts and commitment to be made practical and effective. The processes, alliances and resources management represent this technical structure. Particularly, process management is a broad concept that includes the design and manufacturing of products, the lending of services or the carrying out of internal procedures of the organization with the aim of fulfilling the expectations of customers and other stakeholders. Moreover, process management helps to prevent errors, facilitates control and continuous improvement, moves us closer to the standard of zero defects and fosters innovation (Sila, Ebrahimpour 2003). These aspects have a direct influence on the operational and economic results of any type of business as well as on internal and external customer satisfaction and the involvement of the workers in the organization, and the reputation and good image of the organization in its environment.

This work also answers a question which has not been thoroughly analyzed in the TQM literature: Is the process management a key mediator of the EFQM model? The results of our analysis show us how processes play a mediating role in the relationships that policy \& strategy, and alliances \& resources respectively maintain with results. However, 
we do not find that they play such a mediating role in the effect of people management on the overall results. In this sense, a future research line could be to study, in a larger sample of firms, the potential direct effect that people management may have on the organizational results.

Finally, the objectives, actions and continuous improvement of the quality system must be deployed through the appropriate formulating of its policy and strategy. The main implications for management are the following. For the carrying out of any quality improvement initiative, it is necessary to count on the senior management's leadership and commitment. These management philosophy values must be created and disseminated. Goals and aims that are consistent with these values must be established and an appropriate organization and system for achieving them be created. This commitment has to go hand in hand with a well-defined and implemented policy and strategy that is communicated to all the organization's levels. Their lack hampers the measuring of the effectiveness and efficiency of the organizations or any subsystem, as well as creating an imbalance in the assigning of resources.

Policy and strategy must be based on the future needs and expectations of the stakeholders. Later, planning must be put into practice through specific actions aimed at continuous improvement and the generating of increasingly more value for the parties concerned, That is to say, through an appropriate management system design and the improvement of key processes. In this sense, it is indispensable to count on an indicators system to assess the effectiveness and efficiency of the processes and also to provide the parties concerned with clear information.

On the other hand, organizations must try to optimize the scarce resources that they have (money, information, infrastructure or technology) and carry out an appropriate control and management of the suppliers of specific materials which represent a large budgetary cost. In this way, the appropriate handling of the resources will have a positive effect on the process development and will indirectly affect results.

Processes are links between the way of organizational management and the results that it attains. An appropriate process management leads to better results. In addition, processes have shown be a key significant mediator between strategy, and partnerships $\&$ resources respectively and overall results. When globally valuing these results not all the measures of the results have the same relative importance. In this case, and for firms, the importance of the customer and people results and the key results stand out.

The study has certain limitations that must be considered when it comes to interpreting the results and the conclusions arising from it. A first limitation is caused by the technique used for the model proposed: structural equation modeling, which assumes the linearity of relationships between the latent variables. A second limitation is related to the notion of causality. Although evidence is provided about the causality of the model, this has not really been tested. Our study has considered a soft modeling approach oriented more toward prediction than causality. Thirdly, the design of the research was cross-sectional instead of longitudinal. In this respect, the quality assessment and improvement is a process that develops over time and whose effects are only really 
appreciated in the long term. It would, therefore, be appropriate to follow a longitudinal approach for future research. Finally, the sample is totally made up of profit-seeking entities. Due to this, the possibility of extrapolating the results to public organizations or those whose activity was not prevailingly the need to obtain economic results in the form of profits would be questionable. In this respect, a future research line is opened to aim at identifying significant differences in the way of managing an organization and obtaining results between both types of organizations.

\section{Acknowledgements}

This research was supported by the Junta de Andalucía (Consejería de Economía, Innovación y Ciencia) Spain (Proyecto de investigación de excelencia SEJ-6081).

\section{References}

Ahire, S. L.; Golhar, D. Y.; Waller, M. A. 1996. Development and validation of TQM implementations construct, Decision Sciences 27(1): 23-56.

http://dx.doi.org/10.1111/j.1540-5915.1996.tb00842.x

Ahmad, S.; Schroeder, G. 2002. The importance of recruitment and selection process for sustainability of total quality management, International Journal of Quality and Reliability Management 19(5): 540-550. http://dx.doi.org/10.1108/02656710210427511

Anderson, J. C.; Rungtusanatham, M.; Schroeder, R. G. 1994. A theory of quality management underlying the Deming management method, Academy of Management Review 19(3): 472-509.

Anderson, J. C.; Rungtusanatham, M.; Schroeder, R. G.; Devaraj, S. 1995. A path analytic model of a theory of quality management method: preliminary empirical findings, Decision Sciences 26(5): 637-658. http://dx.doi.org/10.1111/j.1540-5915.1995.tb01444.x

Bou-Llusar, J. C.; Escrig-Tena, A. B.; Roca-Puig, V.; Beltrán-Martín, I. 2009. An empirical assessment of the EFQM Excellence Model: evaluation as a TQM framework relative to the MBNQA model, Journal of Operations Management 27: 1-22.

http://dx.doi.org/10.1016/j.jom.2008.04.001

Calvo-Mora, A.; Leal, A.; Roldán, J. L. 2005. Relationships between the EFQM model criteria: a study in Spanish universities, Total Quality Management 16(6): 741-770.

http://dx.doi.org/10.1080/14783360500077708

Castka, P.; Bamber, C. J.; Sharp, J. M. 2003. Measuring teamwork culture: the use of a modified EFQM model, Journal of Management Development 22(2): 149-170.

http://dx.doi.org/10.1108/02621710310459702

Castka, P.; Bamber, C. J.; Sharp, J. M. 2004. Benchmarking intangible assets: enhancing teamwork performance using self-assessment, Benchmarking: an International Journal 11(6): 571-583.

Chin, W. W. 2003. PLS-Graph, version 3.0. University of Houston, TX.

Claver, E.; Tarí, J. J.; Molina, J. F. 2003. Critical factors and results of quality management: an empirical study, Total Quality Management 14(1): 91-118. http://dx.doi.org/10.1080/14783360309709

Criado, F.; Calvo-Mora, A. 2009. Excellence profiles in Spanish firms with quality management systems, Total Quality Management \& Business Excellence 20(6): 655-679.

http://dx.doi.org/10.1080/14783360902924366

Curkovic, S.; Vickery, S.; Dröge, C. 2000. Quality-related action programs: their impact on quality performance and firm performance, Decision Sciences 31(4): 885-905.

http://dx.doi.org/10.1111/j.1540-5915.2000.tb00947.x 
Dahlgaard-Park, S. M. 2008. Reviewing the European excellence model from a management control view, The TQM Journal 20(2): 98-119. http://dx.doi.org/10.1108/17542730810857345

Davies, J. 2008. Integration: is it the key to effective implementation of the EFQM Excellence Model?, International Journal of Quality \& Reliability Management 25(4): 383-399. http://dx.doi.org/10.1108/02656710810865267

Dean, J. W.; Bowen, D. E. 1994. Management theory and total quality: improving research and practice through theory development, Academy of Management Review 19(3): 392-418.

Eriksson, H.; Garvare, R. 2005. Organisational performance improvement through quality award process participation, International Journal of Quality \& Reliability Management 22(9): 894-912. http://dx.doi.org/10.1108/02656710510625202

Eskildsen, J. K.; Dahlgaard, J. J. 2000. A causal model for employee satisfaction, Total Quality Management 11: 1081-1094. http://dx.doi.org/10.1080/095441200440340

Eskildsen, J. K.; Kristensen, K.; Juhl, H. J. 2004. Private versus public sector excellence, TQM Magazine 16(1): 50-56. http://dx.doi.org/10.1108/09544780410511489

Eskildsen, J. K.; Kristensen, K.; Juhl, H. J. 2001. The criterion weights of the EFQM Excellence Model, The International Journal of Quality \& Reliability Management 18(8-9): 783-795.

http://dx.doi.org/10.1108/EUM0000000006033

European Foundation for Quality Management. 2003. EFQM Excellence Model. European Foundation for Quality Management Brussels.

Farris, J. A.; van Aken, E. M.; Letens, G.; Chearksul, P.; Coleman, G. 2011. Improving the performance review process. A structures approach and case application, International Journal of Operations \& Production Management 31(4): 376-404.

http://dx.doi.org/10.1108/01443571111119524

Flynn, B.; Saladin, B. 2001. Further evidence on the validity of the theoretical models underlying the Baldrige criteria, Journal of Operations Management 19: 617-652.

http://dx.doi.org/10.1016/S0272-6963(01)00072-9

Flynn, B.; Schroeder, R. G.; Sakakibara, S. 1994. A framework for quality management research and an associated measurement instrument, Journal of Operations Management 11(4): 339-366. http://dx.doi.org/10.1016/S0272-6963(97)90004-8

Fotopoulos, C. V.; Psomas, E. L. 2010. The structural relationships between TQM factors and organizational performance, Total Quality Management \& Business Excellence 22(5): 539-552.

Ghobadian, A.; Woo, H. S. 1996. Characteristic, benefits and shortcomings of four major quality awards, International Journal of Operations \& Production Management 13: 10-44.

Hendricks, K. B.; Singhal, V. R. 2001. The long-run stock price performance of firms with effective TQM programs, Management Science 47(3): 359-368.

http://dx.doi.org/10.1287/mnsc.47.3.359.9773

Heras-Saizarbitoria, I.; Marimon, F.; Casadesús, M. 2012. An empirical study of the relationships within the categories of the EFQM model, Total Quality Management 23(5): 523-540.

http://dx.doi.org/10.1080/14783363.2012.669541

Hides, M. T.; Davies, J.; Jackson, S. 2004. Implementation of EFQM excellence model selfassessment in the UK higher education sector - lessons learned from other sectors, The TQM Magazine 16(3): 194-201.

Hung, R. Y. Y. 2006. Business process management as competitive advantage: a review and empirical study, Total Quality Management 17(1): 21-40.

http://dx.doi.org/10.1080/14783360500249836

Jabnoun, N.; Sedrani, K. 2005. TQM, culture and performance in UAE manufacturing firms, The Quality Management Journal 12(4): 8-20. 
Kaynak, H. 2003. The relationship between total quality management practices and their effects on firm performance, Journal of Operations Management (21): 405-435.

http://dx.doi.org/10.1016/S0272-6963(03)00004-4

Kim, D. Y.; Kumar, V.; Murphy, S. A. 2010. European foundation for quality management business excellence model: an integrative review and research agenda, International Journal of Quality \& Reliability Management 27(6): 684-701.

http://dx.doi.org/10.1108/02656711011054551

Lemark, D. J.; Reed, R.; Satish, P. K. 1997. Commitment to quality management: is there a relationship with firm performance?, Journal of Quality Management 2(1): 67-86.

http://dx.doi.org/10.1016/S1084-8568(97)90022-5

MacCallum, R. C.; Browne, M. W. 1993. The use of causal indicators in covariance structure models: some practical issues, Psychological Bulletin 114(3): 533-541.

http://dx.doi.org/10.1037/0033-2909.114.3.533

Nabitz, U.; Jansen, P.; van der Voet, S.; van den Brink, W. 2009. Psychosocial work conditions and work stress in an innovating addiction treatment centre. Consequences for the EFQM Excellence Model, Total Quality Management \& Business Excellence 20(3): 267-281. http://dx.doi.org/10.1080/14783360902719410

Nair, A. 2006. Meta-analysis of the relationship between quality management practices and firm performance - implications for quality management theory development, Journal of Operations Management 24: 948-975. http://dx.doi.org/10.1016/j.jom.2005.11.005

Olaru, M.; Dinu, V.; Stoleriu, G.; Sandru, D.; Dinca, V. 2010. Responsible commercial activity of SMES and specific values of sustainable development in terms of the European excellence model, Amfiteatru Economic 11(27): 10-26.

Pannirselvam, G. P.; Ferguson, L. A. 2001. A study of the relationships between the Baldrige categories, International Journal of Quality and Reliability Management 18(1): 14-34.

http://dx.doi.org/10.3846/16111699.2011.620155

Parasuraman, A.; Zeithaml, V. A.; Berry, L. L. 1994. Reassessment of expectations as a comparison standard in measuring service quality: implications for further research, Journal of Marketing 58: 114-124. http://dx.doi.org/10.2307/1252255

Polites, G. L.; Roberts, N.; Thatcher, J. 2012. Conceptualizing models using multidimensional constructs: a review and guidelines for their use, European Journal of Information Systems 21(1): 22-48. http://dx.doi.org/10.1057/ejis.2011.10

Powell, T. C. 1995. Total quality management as competitive advantage: a review and empirical study, Strategic Management Journal 16: 15-37. http://dx.doi.org/10.1002/smj.4250160105

Prajogo, D. I. 2005. The comparative analysis of TQM practices and quality performance between manufacturing and service firms, International Journal of Service Industry Management 16(3): 217-228. http://dx.doi.org/10.1108/09564230510601378

Prajogo, D. I.; Sohal, A. S. 2004. The multidimensionality of TQM practices in determining quality and innovation performance-an empirical examination, Technovation 24: 443-453.

http://dx.doi.org/10.1016/S0166-4972(02)00122-0

Prajogo, D. I.; Sohal, A. S. 2006. The relationship between organization strategy, total quality management (TQM), and organization performance-the mediating role of TQM, European Journal of Operational Research 168: 35-50. http://dx.doi.org/10.1016/j.ejor.2004.03.033

Preacher, K. J.; Hayes, A. F. 2008. Asymptotic and resampling strategies for assessing and comparing indirect effects in multiple mediator models, Behavior Research Methods 40: 879-891. http://dx.doi.org/10.3758/BRM.40.3.879 
Rahman, S.; Bullock, P. 2005. Soft TQM, hard TQM, and organisational performance relationships: an empirical investigation, Omega 33: 73-83.

http://dx.doi.org/10.1016/j.omega.2004.03.008

Reed, R.; Lemak, D. J.; Mero, P. 2000. Total quality management and sustainable competitive advantage, Journal of Quality Management 5: 5-26.

http://dx.doi.org/10.1016/S1084-8568(00)00010-9

Reinartz, W.; Haenlein, M.; Henseler, J. 2009. An empirical comparison of the efficacy of covariance-based and variance-based SEM, International Journal of Research in Marketing 26: 332-344. http://dx.doi.org/10.1016/j.ijresmar.2009.08.001

Roberts, N.; Thatcher, J. B. 2009. Conceptualizing and testing formative constructs: tutorial and annotated example, The DATA BASE for Advances in Information Systems 40(3): 9-39.

http://dx.doi.org/10.1145/1592401.1592405

Roldán, J. L.; Sánchez-Franco, M. J. 2012. Variance-based structural equation modelling: guidelines for using Partial Least Squares in information systems research, in M. Mora, et al. (Eds.). Research methodologies, innovations and philosophies in software systems engineering and information systems. Hershey, PA: IGI Global, 193-221.

http://dx.doi.org/10.4018/978-1-4666-0179-6.ch010

Santos Vijande, M. L.; Álvarez González, L. I. 2008. Total quality management practices and firm's adoption of technological and administrative innovations, Cuadernos de Economía y Dirección de la Empresas 37: 33-65. http://dx.doi.org/10.1016/S1138-5758(08)70068-9

Santos Vijande, M. L.; Álvarez González, L. I. 2009. TQM's contribution to marketing implementation and firm's competitiveness, Total Quality Management \& Business Excellence 20(2): 171-196. http://dx.doi.org/10.1080/14783360802622953

Sila, I.; Ebrahimpour, M. 2003. Examination and comparison of the critical factors of total quality management (TQM) across countries, International Journal of Production Research 41(2): 235-268. http://dx.doi.org/10.1080/0020754021000022212

Sila, I.; Ebrahimpour, M. 2005. Critical linkages among TQM factors and business results, International Journal of Operations \& Production Management 25(11): 1123-1155.

http://dx.doi.org/10.1108/01443570510626925

Soltani, E.; Gennard, J.; van Der Meer, R. B.; Williams, T. 2004. HR performance evaluation in the context of TQM, International Journal of Quality \& Reliability Management 21(4): 377-396. http://dx.doi.org/10.1108/02656710410530082

Sousa, R.; Voss, C. A. 2002. Quality management re-visited: a reflective review and agenda for future research, Journal of Operations Management 20: 91-109.

http://dx.doi.org/10.1016/S0272-6963(01)00088-2

Tenenhaus, M.; Esposito Vinzi, V.; Chatelin, Y. M.; Lauro, C. 2005. PLS path modeling, Computational Statistics and Data Analysis 48: 159-205. http://dx.doi.org/10.1016/j.csda.2004.03.005

Tutuncu, O.; Kucukusta, D. 2007. Relationship between organizational commitment and EFQM business excellence model: a study on Turkish quality award winners, Total Quality Management 18(10): 1083-1096. http://dx.doi.org/10.1080/14783360701594709

Tutuncu, O.; Kucukusta, D. 2010. Canonical correlation between job satisfaction and EFQM business excellence model, Quality \& Quantity 44(6): 1227-1238.

http://dx.doi.org/10.1007/s11135-009-9269-0

Williams, R.; Bertsch, B.; Van der Wiele, A; Van Iwaarden, J.; Dale, B. 2006. Self-assessment against business excellence models: a critique and perspective, Total Quality Management 17(10): 1287-1300. http://dx.doi.org/10.1080/14783360600753737 
Winn, B. A.; Cameron, K. S. 1998. Organizational quality: an examination of the Baldrige National Quality framework, Research in Higher Education 39(5): 491-512. http://dx.doi.org/10.1023/A:1018745505108

Wrong, A. 2002. Sustaining company performance through partnering with suppliers, International Journal of Quality \& Reliability Management 19(5): 567-580. http://dx.doi.org/10.1108/02656710210427539

Yousefie, S.; Mohammadi, M.; Monfared, J. H. 2011. Selection effective management tools on setting European Foundation for Quality Management (EFQM) model by a quality function deployment (QFD) approach, Expert Systems with Applications 38: 9633-9647.

http://dx.doi.org/10.1016/j.eswa.2011.01.166

Zairi, M.; Alsughayir, A. A. 2011. The adoption of excellence models through cultural and social adaptations: an empirical study of critical success factors and a proposed model, Total Quality Management \& Business Excellence 22(6): 641-654.

http://dx.doi.org/10.1080/14783363.2011.580654

Eva SUÁREZ is an experienced consultant on advanced management systems. She works in a Technological Centre of Engineering and Knowledge Management. She has coordinated more than 100 evaluation processes using the EFQM model and she has designed and implemented evaluation systems. She has also taken part in a number of European projects concerning innovation and technology management. Her latest works have been published in the scientific magazines Tourism \& Management Studies and Papers de Tourisme. Quality management, business economy, knowledge management, tourism management and PLS methodology are among her investigation concerns.

José L. ROLDÁN, Dr, is Associate Professor of Management at the Faculty of Economics and Business Administration, University of Seville (Spain). He has lately contributed to publications such as the British Journal of Management, European Journal of Information Systems, International Small Business Journal, Computers in Human Behavior, Handbook of Partial Least Squares, Industrial Marketing Management, International Journal of Technology Management, and Internet Research. Currently he is on the editorial board of The Database for Advances in Information Systems, and was guest editor of the European Journal of Information Systems' Special Issue on Quantitative Research Methodology. He is keen on researching in business intelligence, social network sites and PLS methodology, among other areas.

Arturo CALVO-MORA, Dr, is Associate Professor of Management at the Faculty of Economics and Business Administration and at the Faculty of Tourism and Finance, University of Seville (Spain). His recent contributions have been published in Journal of Business Research, Total Quality Management \& Business Excellence, International Journal of Operations \& Production Management, Quality Assurance in Education, Tourism \& Management Studies, Papers de Tourisme and the Revista Europea de Dirección y Economía de la Empresa. Additionally, he has participated in a number of European projects related to tourism, innovation and technology management. His research interests include quality management, knowledge management, business economy, tourism management and PLS methodology. 